\title{
Diversity of Phytoplanktonic populations along the Algerian coastline
}

\author{
Mustapha Boudjenah",2,*, Zakia Mokrane² \& Dina Soualili'
}

${ }^{1}$ Department of Marine Sciences and Aquaculture, Faculty of Natural Sciences and life, Abedelhamid Ibn Badis University, BP 227, Mostaganem, Algeria; e-mail: boudjenahmust@yahoo.fr, soualilid@yahoo.fr

${ }^{2} \mathrm{CNRDPA} /$ National Center for Research and Development of Fisheries and Aquaculture, 11 Boulevard Amirouche, BouIsmail, Tipaza, Algeria; e-mail: mokrane.zakia@gmail.com

${ }^{*}$ Corresponding author

ABSTRACT

Phytoplankton biodiversity is the basis of the functioning of the aquatic ecosystems. Also, understanding and evaluating the effects of the change in our environment and their impact on planktonic populations is an important element. In fact, this paper was to appreciate the diversity and composition of phytoplankton in relation to some physicochemical parameters. Water samples were collected along the Algerian coastline (Alboran Sea, the Algerian basin and the Middle area), during the period May-June 2013. The study area contained a diversified phytoplankton community (296 species), belonging to 138 genera. The algal groups were represented and classified as dinoflagellates (180 species), diatoms (103 species), cyanophyceae, coccolithophorids, euglenids, and chrysophytes (13 species). The spatial distribution of cell densities revealed a heterogeneous phytoplankton composition dominated by dinoflagellates, which represent $63 \%$ of the total abundance, followed by diatoms (35\%). Quantitatively, we observed a highest cell density and diatoms abundance in most stations of the Alboran Sea decreasing towards the east (Algerian basin). The peak of dinoflagellates in June was represented by Prorocentrum and Gymnodinium genera.

KEY WORDS Phytoplankton; diversity; physicochemical parameters; diatoms; dinoflagellates.

Received 06.02.2019; accepted 28.03.2019; published online 08.05.2019.

\section{INTRODUCTION}

Phytoplankton is an important element in the marine ecosystem; this community is the basis of marine and freshwater food webs. Any change leads to variation of the trophic systems (Somoue et al., 2013), their composition fluctuations depending on hydrological conditions, such as light, temperature, salinity, $\mathrm{pH}$, nutrients, and turbulence. Phytoplankton is known to exhibit rapid responses to changes in environmental conditions and is therefore commonly acknowledged as an excellent bioindicator of the impact of natural and seasonal changes in coastal ecosystems (Rimet \& Bouchez, 2011). Changes in dominant base groups/species often propagate up the food chain, impacting on fish, marine mammals, and birds (Donnelly et al., 2007). Their susceptibility to environmental change is usually expressed by morphological and/or behavioral changes as well as by persistent or seasonal differences in abundance and distribution (Leterme et al., 2013). Qualitative and quantitative studies of phytoplankton allow us to recognize and describe the morphology of species, 
and to analyse the dynamics of populations in time and space.

In recent years, "massive" growth of some phytoplanktonic species has been recorded along the Algerian coastline. These blooms are often linked to the eutrophication and anthropization of aquatic environments, and the nuisance that can be caused by hundreds of species may potentially present a risk to public health (David et al., 2012).

The information, concerning the composition of the phytoplankton community of the Algerian coast comes mainly from specific studies, referred to certain zones. While global data from across the Algerian coast are missing from the literature, nevertheless protection of marine ecosystems is a priority in the national development program of aquaculture and fishing activities in Algeria (Plan Aquapeche 2020, 2014).

The present study aims to explore the diversification and structure of phytoplankton populations observed on the Algerian coast during the period from May to June 2013 observed as a result of the analysis of the data collected during the prospecting Oceanographic campaign. It will reveal phytoplankton composition in three different zones of the Algerian coast, namely: the Alboran Sea, the Algerian basin and the Middle area.

The main hypothesis of this work is the influence of Atlantic waters on the structure of phytoplankton assemblages essentially, the diatom to dinoflagellate ratio.

This study will provide important information for future research, in relation to observed changes in the structure of the phytoplankton community due to the combined pressure of climate change and human impact in the Mediterranean.

\section{MATERIAL AND METHODS}

\section{Study area}

To gather information on different (qualitative and quantitative) aspects of the phytoplankton population along the Algerian coastline, the study was based on data collected during the assessment of demersal resources "ALDEM 2013" by CNRDPA (National Center for Research and Development Fisheries and Aquaculture).

The assessment of demersal resources "ALDEM
2013", which took place from May to June (2013) aboard the research vessel "Grine Belkacem", concerned the trawl bottoms of the Algerian coast at a depth from 20 to $800 \mathrm{~m}$ (Plateau and continental slope), Cape Segleb (36 $56^{\prime} 45^{\prime \prime} \mathrm{N}$ - 8 $\left.8^{\circ} 36^{\prime} 57^{\prime} \mathrm{E}\right)$, Algerian-Tunisian borders to Wadi Kiss ( $35^{\circ} 3^{\prime} 49^{\prime \prime} \mathrm{N}$ $2^{\circ} 12^{\prime} 50^{\prime \prime} \mathrm{W}$ ), Algerian-Moroccan borders. The Algerian coastline (Fig. 1) has been divided into three sectors: 1) the Alboran Sea: located in the western region of the Mediterranean Sea; its maximum width is $180 \mathrm{~km}$ at its eastern part, and a minimum of $14 \mathrm{~km}$ at the Strait of Gibraltar. The distance from the Strait of Gibraltar to the line between Cap de Gata (Almeria, Spain) and Cape Fegalo (Oran, Algeria) is $350 \mathrm{~km}$. This imaginary line does not define a strict physical boundary, but an approximate delimitation of ecological processes and fluctuations in physical characteristics; 2) the Middle area: between the eastern limit of the Alboran Sea and the western boundary of the Algerian basin, goes from the wilaya of Tipasa to Tizi-Ouzou; 3) the Algerian basin: in the center of the western Mediterranean Sea, between the Algerian coasts and the Balearic Islands on the western side and the island of Sardinia on the east coast. Its width can reach about $280 \mathrm{~km}$ and extends over a length of about $500 \mathrm{~km}$ (Riandey et al., 2005).

In the present work, we named by "wilaya" a sampling site related to an administrative division (In English, Prefecture).

\section{Sampling strategy and methods of phyto- plankton analysis}

The radials were selected in a grid pattern across the study region. During this campaign, in-situ hydrological measurements (temperature and salinity records) were carried out vertically by a CTD probe (Sea-Bird SBE 19 plus) and horizontally by a thermo-salinograph (Sea- Bird SBE 21) installed on board of the Research vessel. About 11 stations were chosen for the treatment and study of phytoplankton in this work, the position of these deferent study areas (Wilaya) is noted in Table I.

The phytoplankton dynamics study was divided into three distinct stages, i) sampling; ii) fixation, observation of the samples; and, finally, iii) the graphic and statistical processing of the data.

Sampling. Seawater for qualitative and quantitative study was carried out using 5 liter capacity 
Niskin PVC bottles. The treatment protocol of this stand adopted in this study was based on the standards related to the Utermöhl method (Utermöhl, 1958). Phytoplankton were field-fixed immediately with Lugol's solution, conserved at low temperature $\left(4^{\circ} \mathrm{C}\right)$ and in the dark to avoid photosynthesis. Finally, to achieve sedimentation of samples, each bottle was gently agitated for at least one minute, to homogenize its content. Utermöhl tanks were placed in sedimentation chambers $(100 \mathrm{ml}$ and $50 \mathrm{ml})$. The sedimentation time varied according to volume, from 24 to 72 hours (Ignatiades et al., 2009).

Observation and identification of species. Phytoplankton analysis was carried out in accordance with the recommendations of the Guide Standard for the Counting of Phytoplankton by Reverse Microscopy - Standard (Norme européenne NF EN 15204, 2006) of December 2006 - corresponding to Utermöhl method. A camera was very useful for validations of identifications and measurements.
Determination of phytoplankton species was carried out at the specific level or, in case of difficulty or uncertainty, at higher taxonomic level (genus, family or class) using several keys and/or catalogues (Meunier, 1915; Schiller, 1933-1937; Taylor, 1976; Meave-del Castillo, 2009; Meave-del Castillo et al., 2012). Then, phytoplankton species were updated according to main taxonomic database sites, like algaebase.com, and World Register of Marine Species (WoRMS, 2019).

Data analysis. In this section, we were also interested in the variations of cell density of different species and genera in each station.

\section{Diversity and structure of phytoplanktonic populations}

Three main indices have been used, namely Shannon-Wiener, Equitability and Simpson.

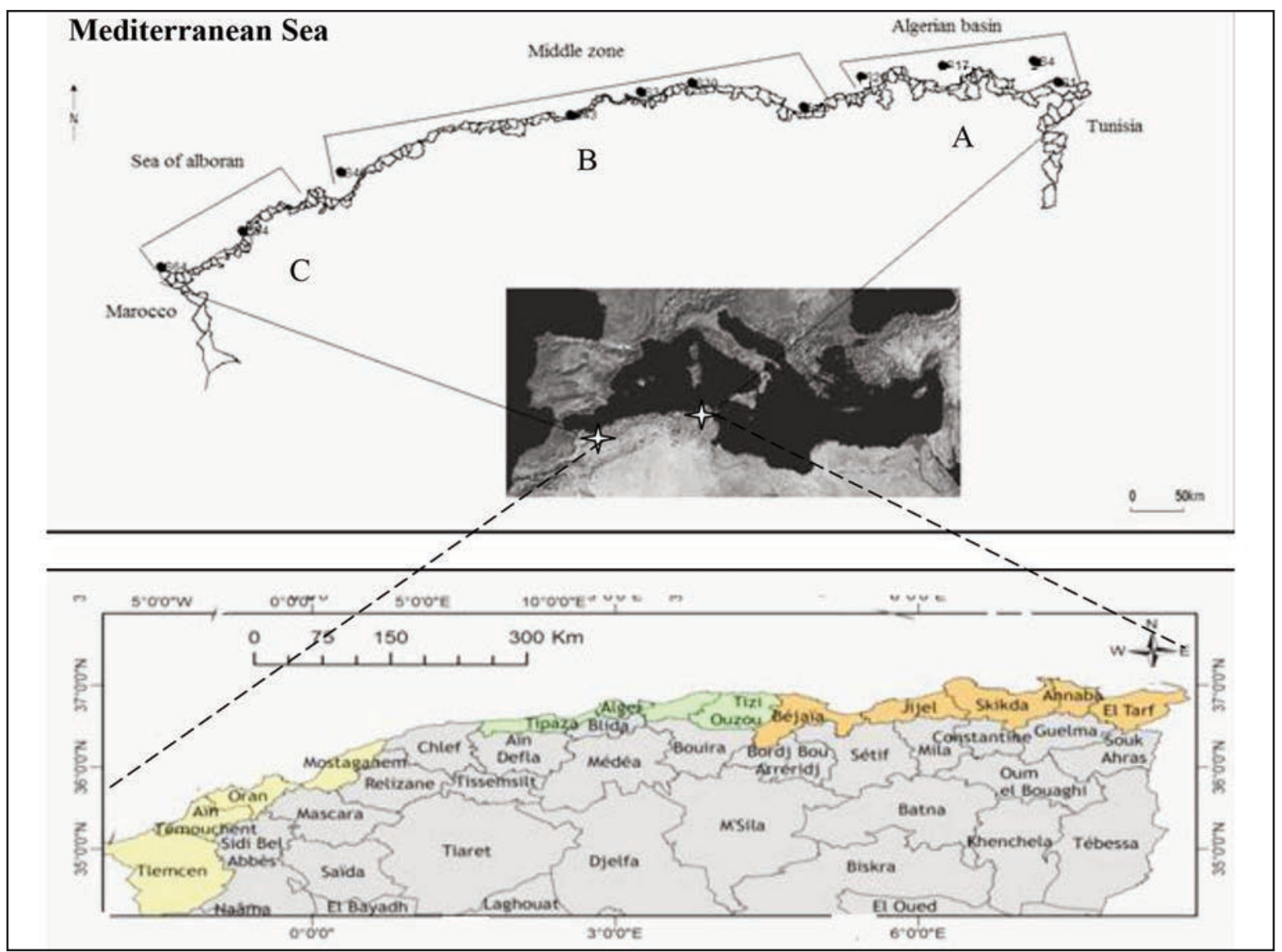

Figure 1. Localization of the study areas (site/wilaya) and subdivision of the Algerian coast. A: Algerian basin; B: Middle area; C: Alboran Sea. 


\begin{tabular}{|c|c|c|c|c|c|}
\hline Zones & Wilaya & Stations & Longitude & Latitude & $\begin{array}{l}\text { Distance to } \\
\text { coast } / \mathrm{m}\end{array}$ \\
\hline \multirow{4}{*}{$\begin{array}{l}\text { Algerian } \\
\text { basin }\end{array}$} & El Taref & S1 & $36^{\circ} 55^{\prime} 53.4606^{\prime \prime}$ & $8^{\circ} 18^{\prime} 10.8^{\prime \prime}$ & 1700 \\
\hline & Annaba & S11 & $37^{\circ} 8^{\prime} 43.0182^{\prime \prime}$ & $8^{\circ} 1^{\prime} 14.4588^{\prime \prime}$ & 28000 \\
\hline & Skikda & S12 & $37^{\circ} 1^{\prime} 18.12^{\prime \prime}$ & $7^{\circ} 14^{\prime} 6.7806^{\prime \prime}$ & 1900 \\
\hline & Jijel & S24 & $36^{\circ} 54^{\prime} 44.9388^{\prime \prime}$ & $6^{\circ} 3^{\prime} 10.6806^{\prime \prime}$ & 5100 \\
\hline \multirow{5}{*}{$\begin{array}{l}\text { Middle } \\
\text { area }\end{array}$} & Bejaia & S26 & $36^{\circ} 41^{\prime} 18.3588^{\prime \prime}$ & $5^{\circ} 19^{\prime} 50.6388^{\prime \prime}$ & 4800 \\
\hline & Tizi-Ouzou & $\mathrm{S} 30$ & $36^{\circ} 55^{\prime} 21.7626^{\prime \prime}$ & $4^{\circ} 1^{\prime} 25.3194^{\prime \prime}$ & 2000 \\
\hline & Boumerdes & S34 & $36^{\circ} 50^{\prime} 14.5212^{\prime \prime}$ & $3^{\circ} 25^{\prime} 29.8194^{\prime \prime}$ & 7000 \\
\hline & Tipasa & S43 & $36^{\circ} 36^{\prime} 59.1006^{\prime \prime}$ & $2^{\circ} 35^{\prime} 56.6406^{\prime \prime}$ & 800 \\
\hline & Mostaganem & S46 & $36^{\circ} 3^{\prime} 7.2606^{\prime \prime}$ & $-0^{\circ} 5^{\prime} 56.8788^{\prime \prime}$ & 19000 \\
\hline \multirow[t]{2}{*}{$\begin{array}{l}\text { Alboran } \\
\text { Sea }\end{array}$} & $\begin{array}{l}\text { Ain- } \\
\text { Temouchent }\end{array}$ & S54 & $35^{\circ} 29^{\prime} 2.8782^{\prime \prime}$ & $-1^{\circ} 14^{\prime} 25.9188^{\prime \prime}$ & 1200 \\
\hline & Tlemcen & S64 & $35^{\circ} 7^{\prime} 44.4606^{\prime \prime}$ & $-1^{\circ} 11^{\prime} 39.0114^{\prime \prime}$ & 4000 \\
\hline
\end{tabular}

Table 1. Geographical coordinates for each sampled site (wilaya) by region and its distance to the coast.

The Shannon Index indicates the number of species in a community in relation with stability of the environment; When the index is high, it is explained by a stable environment. This index is given by the following formula:

$$
\mathrm{H}^{\prime}=\mathrm{ISh}=-\sum \mathrm{Pi} \cdot \log \mathrm{Pi}, \mathrm{Pi}=\mathrm{ni} / \mathrm{N}
$$

Pi: specific abundance; N: total number of phytoplankton population considered;

ni: number of individuals of the species " $i$ ".

This index varies in a range of $-\log \mathrm{S}$ and $+\log$ $\mathrm{S}$ (S specific richness); The unit of information is the Bits.ind-1.

Equitability index: since diversity depends on both relative frequencies of the species and number of species that can vary widely from one stand to another,it is defined by the formula:

$$
\mathrm{E}(\mathrm{R})=\mathrm{ISh}(\text { bits }) / \log _{2} \mathrm{~S} \text { (bits) }
$$

Equitability Index varies between " 0 " and " 1 "; it tends towards " 0 " when most of the cell density is concentrated on one species; it tends to " 1 " when all species have nearly the same abundance.

Simpson Diversity index (L): this index meas- ures the probability that two individuals randomly selected belong to the same species for each given sample. It is given by the formula:

$$
\mathrm{L}=\sum \mathrm{e}[\mathrm{ni}(\mathrm{ni}-1)] /[\mathrm{N}(\mathrm{N}-1)]
$$

$\mathrm{ni}=$ number of individuals in species $\mathrm{i}, \mathrm{N}=$ total number of individuals. The index is inversely proportional to diversity. When diversity is maximal its value is 0 ; when diversity is minimal the value tends to 1 .

Diatoms/Dinoflagellates index: "Dia/Dino" index reflects the dominance patterns in the phytoplankton composition (Abundance or Biomass) (Helcom, 2014, 2016). The Dia/Dino index is defined by the following formula (Wasmund et al., 2017).

$\mathrm{Dia} /$ Dino index $=\mathrm{Ab}_{\text {Dia }} /\left(\mathrm{Ab}_{\text {Dia }}+\mathrm{Ab}_{\text {Dino }}\right)$

$\mathrm{Ab}_{\text {Dia }}=$ Diatoms abundance; $\quad \mathrm{Ab}_{\text {Dino }}=\mathrm{Di}-$ noflagellates abundance.

Seasonal averages of the biomass of planktonic diatoms $\left(\mathrm{BM}_{\mathrm{Dia}}\right)$ have to be divided by the combined biomass or abundance $\left(\mathrm{Ab}_{\mathrm{Dia}}\right.$ or $\left.\mathrm{BM}_{\mathrm{Dia}}\right)$ of planktonic diatoms and autotrophic + mixotrophic dinofla- 
gellates $\left(\mathrm{Ab}_{\text {Dino }}\right.$ or $\left.\mathrm{BM}_{\text {Dino }}\right)$. This leads to a simple absolute measure with values ranging from 0 to 1 . If diatoms dominate, the value of the Dia/Dino index is $>0.5$; if autotrophic + mixotrophic dinoflagellates are dominant, the value of the index is $<0.5$.

Principal component analysis (PCA): is a statistical procedure that uses an orthogonal transformation to convert a set of observations of possibly correlated variables. This analysis was based on correlation matrices applied to the parameters used in the study.

\section{RESULTS}

The inventory of phytoplankton species gives a total of 296 species distributed over the Algerian coast, grouped in 138 genera. In general, dinoflagellates are dominant with 180 species, followed by diatoms with 103 species. Another less frequent group was considered, it gathers the classes of Cyanobacteria, Euglenophyceae and Chlorophyceae (Figs. 2, 3 ). On the spatial level, the number of diatom species is higher in the Alboran Sea, inversely to the Algerian basin where dinoflagellates species are dominant. Equilibrium between diatoms and dinoflagellates was noted in the middle area. The specific richness " $\mathrm{S}$ " along the Algerian coastline is 296 species. It varies from one station to another and from one area (Wilaya) to another with an average value of 45 species. The lowest values were recorded in the Alboran Sea, precisely in both wilaya of Ain-Temouchent and Tlemcen with respective

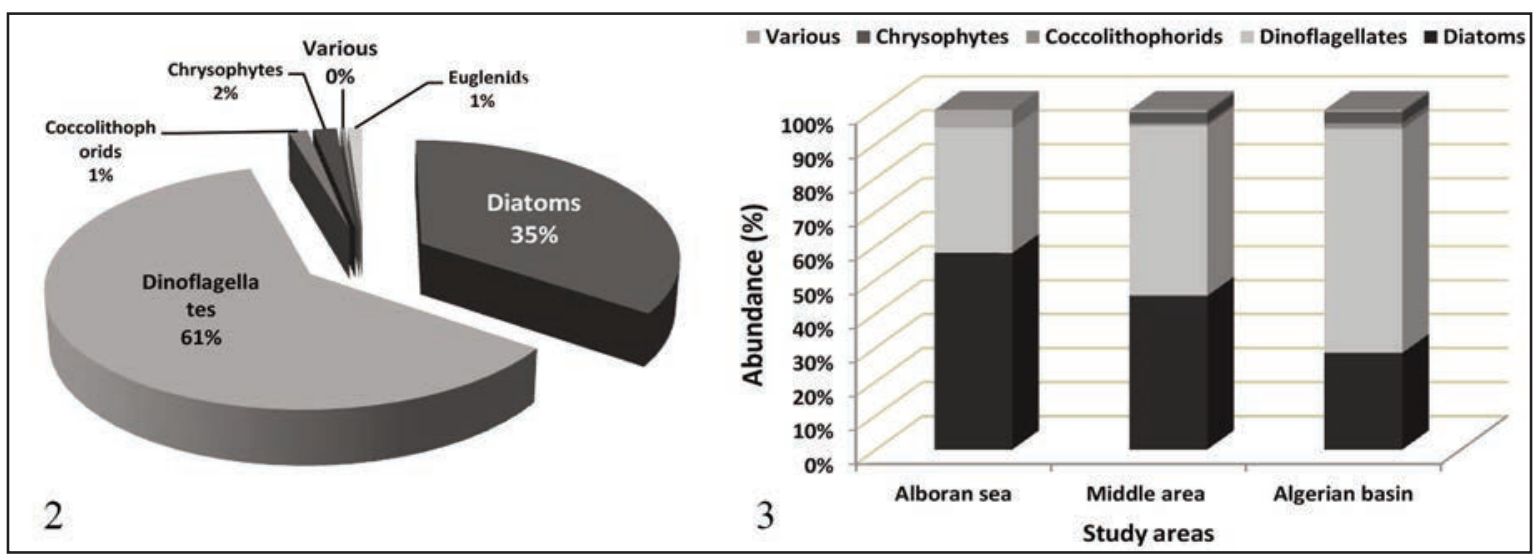

Figures 2, 3. Specific richness "S" of the phytoplankton groups recorded in the study areas of the Algerian coastline. Fig. 2: specific richness of the phytoplankton groups. Fig. 3: spatial variation of the specific richness.

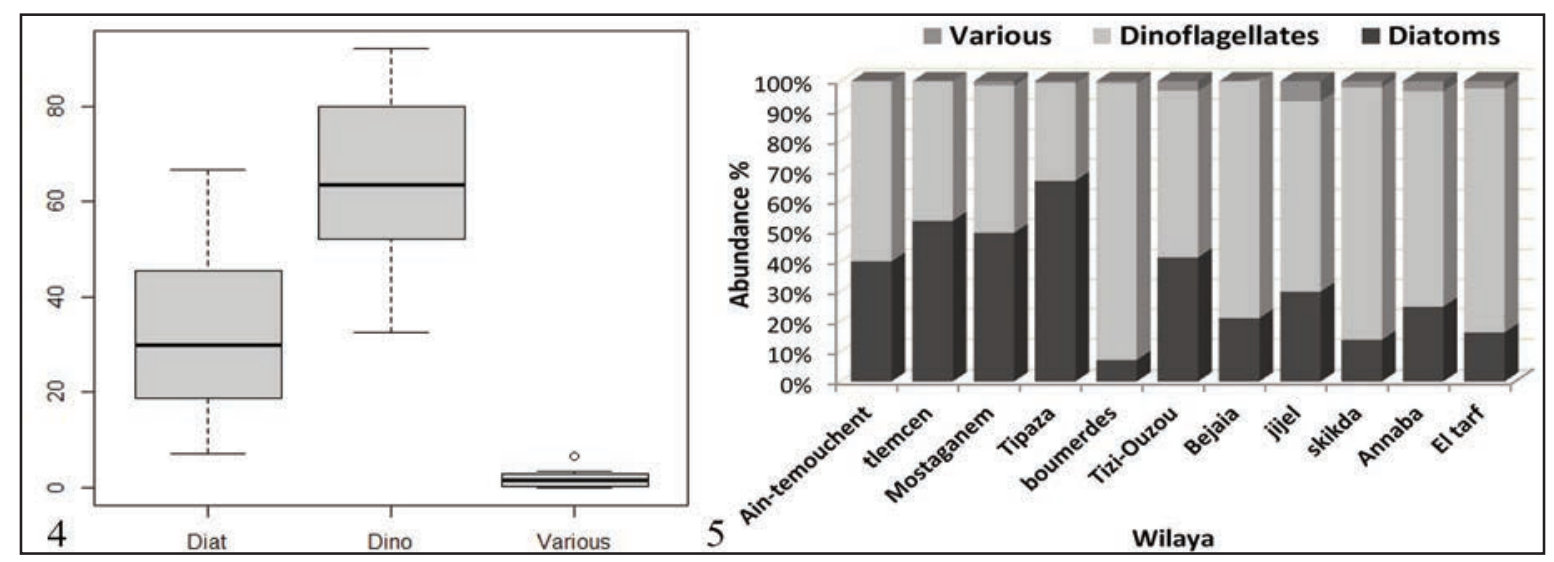

Figures 4, 5. Abundance of phytoplankton groups along the Algerian coastline. Fig. 4: abundance of phytoplanktonic groups presented in box and whiskers plot. Fig. 5: spatial variation of phytoplanktonic groups abundance. 
values of 24 and 13 species. The most represented taxa in this zone are Navicula sp. and Gymnodiuim $\mathrm{sp}$. Indeed, we recorded the highest specific richness values in the Algerian basin at the areas of Skikda and El-Tarf with respective values of $\mathrm{S}=108$ and $\mathrm{S}=74$ species. The observations recorded during our study show that the most important relative frequencies are due to the genera Prorocentrum and Gymnodinium in the Algerian basin. The Middle area specific richness varied between 28 and 47 species and the most important taxa observed were: Prorocentrum mecans, Peridinium sp., in Tizi-Ouzou and Chaetoceros sp., in Tipaza.

The results detailed in figures 4,5 show the frequency and abundance variation of dominant phytoplanktonic groups at the target wilaya of three regions (Alboran Sea, Middle area and Algerian basin). For frequency (F), dinoflagellates and diatoms are the most frequent and constant phytoplankton groups $(\mathrm{F}>50 \%)$ compared to other taxonomic groups. The remainder of the phytoplankton composition indicates that the coccolithophorids are the rarest group $(\mathrm{F}<25 \%)$. This explains the fact that they are less competitive than the other microalgae. On the side of the Alboran sea we have an important presence of the diatoms with $\mathrm{F}>50 \%$ in both stations (Tlemcen, AinTemouchent). On the other hand, dinoflagellates constituted the constant phytoplankton groups in the different area of Algerian basin (Jijel, Skikda, Annaba, and El-Tarf). We noted, in the Middle area, a large frequency of diatoms in Tipaza wilaya, which

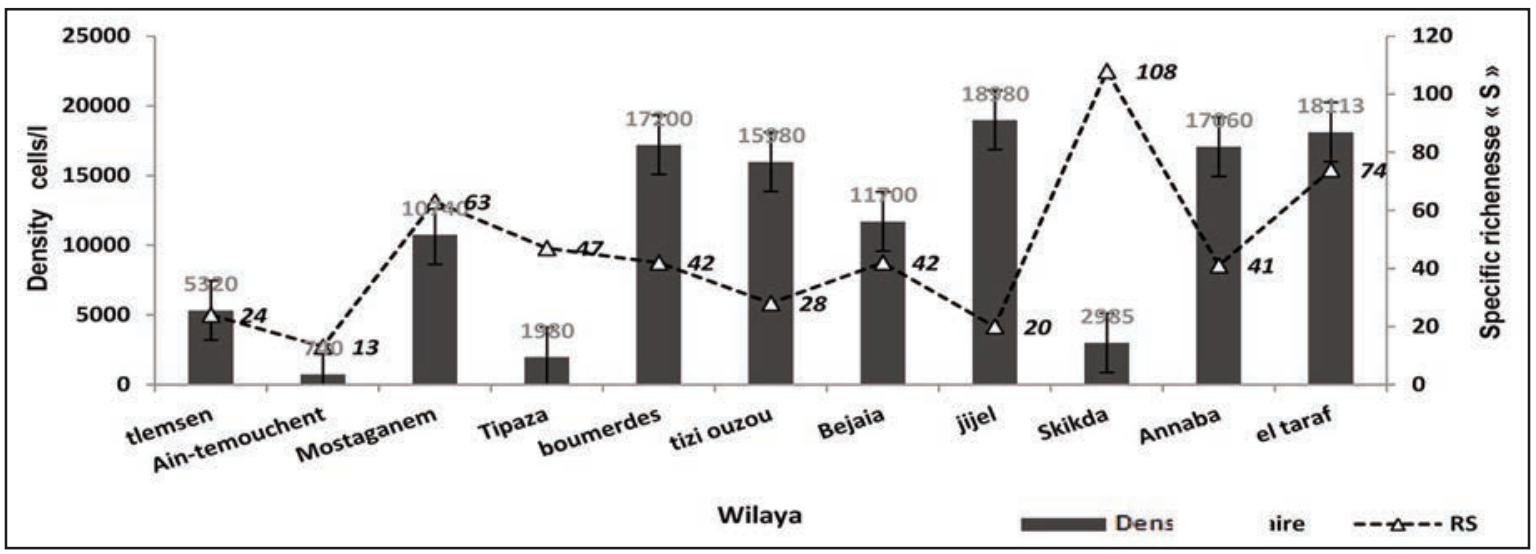

Figure 6. Spatial variation of the phytoplankton cell density in the study areas of the Algerian coastline (Average values).

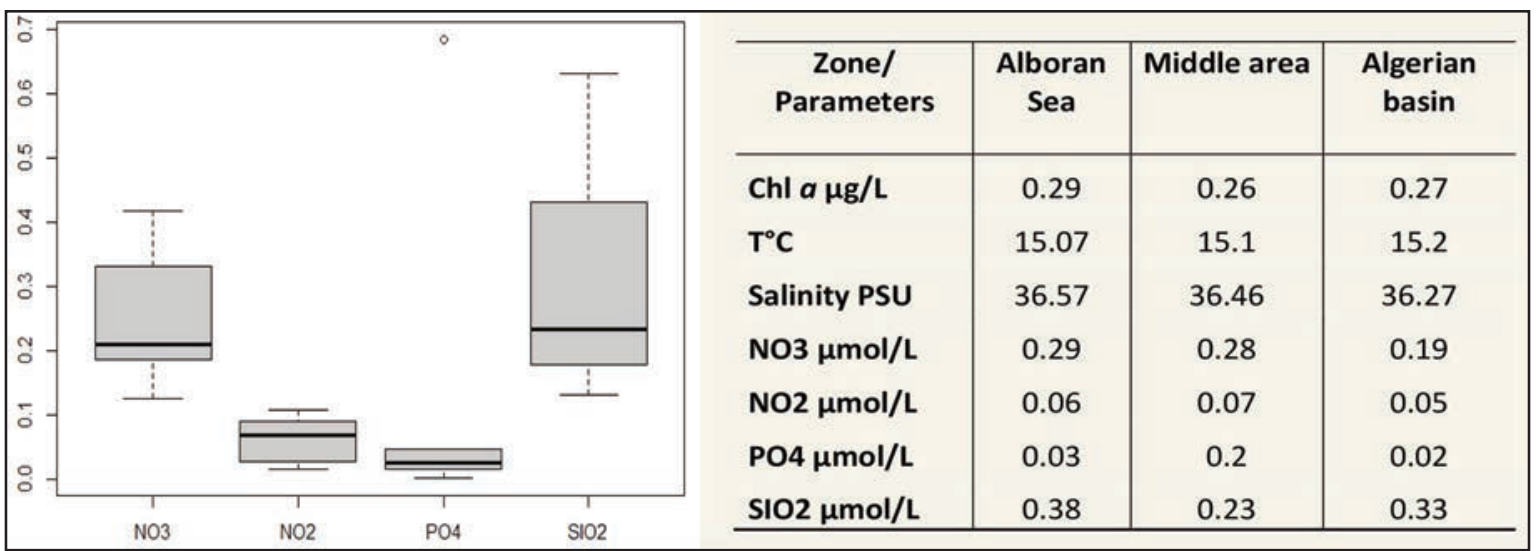

Figure 7. Nutrients of samples collected from the Algerian coastline and spatial variations of environmental parameters. 
is the closest to the eastern limit of the Alboran Sea. Whereas, on the other side, Tizi-Ouzou shows a dominance of dinoflagellates.

The observations recorded during our study, show that the most important relative frequencies are those of the genera Prorocentrum and Gymnodinium ( $\mathrm{F}=58 \%$ and $\mathrm{F}=30 \%$, respectively). In Diatoms, we recorded a relatively high value of the genera Coscinodiscus, Chaetoceros, Melosira and Thalassiosira, while the other genera of diatoms and dinoflagellates are marked by low frequencies $(\mathrm{Fr}<25 \%)$.

The preceding statement is also confirmed by the relative abundance values ( $\mathrm{Ab} \%$ ) of diatoms which largely exceed the average value of $50 \%$ in the majority of stations of the Alboran Sea and slightly exceedes $35 \%$ in the wilaya of the Middle area. We have a phytoplankton abundance that is above average value in the different stations of the Algerian basin; indeed dinoflagellates contribute significantly to quantitative richness in this region with proportions exceeding $70 \%$.

Figure 6 illustrates the distribution of total cell densities found in each region (Alboran Sea, Middle area and Algerian basin). We noted that low cell density was recorded at the wilayas of AinTemouchent, Tipaza and Skikda; while in the wilayas of Jijel, Annaba, Tizi-Ouzou and Boumerdes, we have a high cell density. Analysis of the diatom and dinoflagellate densities in phytoplankton populations shows that in the:

Alboran Sea: diatoms varied from 240 to 10200 cells/L and dinoflagellates from 360 to 10100 cells/L. The recorded observations show the lowest total cell density recorded along the Algerian coastline (740 cells /L) in Ain-Temouchent.

Algerian basin: the recorded observations show a total cell density ranging from 2985 cells/L (Skikda) to 18980 cells/L (Jijel) with large dominance of dinoflagellate groups.

Middle area: Dinoflagellates contribute significantly to phytoplankton production in this region. Wilaya of Boumerdes showed the highest phytoplankton total cell density in this sector; on the other hand, wilaya of Tipaza recorded the lowest concentration.

In Some Wilaya stations we noted a high phytoplanktonic concentration, corresponding to a low specific richness, which means that the population of these areas is dominated by one or two species (Gymnodinium sp.; Prorocentrum sp. in case of dinoflagellates; and Melosira sp. and Chaetoceros sp. in case of Diatoms).

\begin{tabular}{|c|c|c|c|c|c|}
\hline Zone & $\begin{array}{l}\text { Station } \\
\text { (Wilaya) }\end{array}$ & Diatoms & Dinoflagellates & Dominant species & $\begin{array}{c}\text { Diat/Dino } \\
\text { index }\end{array}$ \\
\hline \multirow[t]{3}{*}{ Alboran Sea } & Tlemcen & 2720 & 2360 & Gymnodinium $\mathrm{sp}$ & 0.54 \\
\hline & $\begin{array}{l}\text { Ain- } \\
\text { Temouchent }\end{array}$ & 240 & 360 & Navicula $\mathrm{sp}$ & 0.40 \\
\hline & Mostaganem & 10200 & 10100 & $\begin{array}{l}\text { Melosira } \mathrm{sp} / \\
\text { Gymnodinium } \mathrm{sp}\end{array}$ & 0.51 \\
\hline \multirow[t]{4}{*}{ Middle area } & Tipaza & 2500 & 1220 & Chaetoceros sp & 0.67 \\
\hline & Boumerdes & 6980 & 9360 & Gymnodinium sp & 0.43 \\
\hline & Tizi-Ouzou & 1140 & 14600 & $\begin{array}{l}\text { Prorocentrum } \\
\text { micans }\end{array}$ & 0.07 \\
\hline & Bejaia & 4840 & 18080 & Prorocentrum sp & 0.21 \\
\hline \multirow{4}{*}{$\begin{array}{l}\text { Algerian } \\
\text { basin }\end{array}$} & Jijel & 5680 & 12040 & Gymnodinium sp & 0.32 \\
\hline & Skikda & 2700 & 16320 & Gymnodinium sp & 0.14 \\
\hline & Annaba & 7700 & 22180 & Gymnodinium sp & 0.26 \\
\hline & El Tarf & 8620 & 42900 & Prorocentrum sp & 0.17 \\
\hline
\end{tabular}

Table 2. Spatial variation of Dia/Dina index in the study areas. 
The Dia/Dino index shows only abundance data on diatoms and dinoflagellates (Table 2). It reflects the dominance patterns in the phytoplankton, the average value being around 0.5. As reported above, diatom dominance, (Dia/Dino index $>0.5$ ), was observed in two wilayas of the Alboran Sea area (Tlemcen; Mostaganem). In the wilayas of the Middle area the values of this index varied between 0.07 (Tizi-ouzou) and 0.67 (Tipaza). The minimum average value of this index was recorded in the eastern region confirming the dominance of the dinoflagellates, especially in Skikda.

The Shannon H' Index ranges from 0.86 to 1.9 bit/ind along the Algerian coastline (Table 3). These values are very close to the values of Hmax $(\log \mathrm{S})$, which varied between 1.3 and $2.02 \mathrm{bit} /$ ind. The lowest value of this index $\left(\mathrm{H}^{\prime}=0.86 \mathrm{bit} / \mathrm{ind}\right)$ was recorded in the wilaya of Tizi-Ouzou (Middle area) which moves away from the optimal value of Hmax. The wilaya of Skikda (Alboran Sea) was the most diversified area, as it presents the values closest to the optimal value $\left(\mathrm{H}^{\prime}=1.85 \mathrm{bit} / \mathrm{ind}\right)$. The values of the equitability index (E) of each wilaya oscillate between 0.56 and 0.92 . The minimum (tending to 0) is related to the wilayas of El Taref and Tizi-Ouzou, which means a specific dominance of a particular species or two, thus displaying an irregular spatial distribution. Actually, Prorocentrum sp. and Gymnodinium sp. resulted to dominate with $58 \%$ and $29 \%$ of relative abundance, respectively.

In the wilaya of Tipaza the maximum value of the index tends to " 1 ", thus giving the image of a most diversified population with an equi-distribution. The spatial variation of the Equitability index is in decreasing order among the three studied regions, from the Aboran Sea (0.84) towards the Algerian basin (0.75). Conversely, the Simpson index shows average values increasing from the Alboran Sea (0.10) towards the Algerian basin (0.13).

The results of the spatial variations of temperature $\left({ }^{\circ} \mathrm{C}\right)$, Chlorophyll a $(\mathrm{Chla}$, in $\mu \mathrm{g} / \mathrm{L})$ value, Salinity (P.S.U), and the nutrients $\mathrm{PO}_{4}{ }^{3-}, \mathrm{NO}_{3}{ }^{2-}$, $\mathrm{NO}_{2}$ 2- and $\mathrm{SiO}_{2}(\mu \mathrm{mol} / \mathrm{L})$ of seawater samples collected from the Algerian coastline during May-June 2013 are shown in figure 7.

The normal thermal cycle was clear in this study period, and it was typical in all sector, ranging from a minimum of $14.6^{\circ} \mathrm{C}$ at Ain-Temouchent (Alboran Sea) and a maximum of $15.9^{\circ} \mathrm{C}$ at Skikda (Algerian basin), with a spatial mean value of $15.13^{\circ} \mathrm{C}$ in the Algerian coastline.

The highest value of Chla, was recorded during this period at the Alboran Sea region precisely at Tlemcen $(0.34 \mu \mathrm{mol} / \mathrm{L})$ and the lowest at Skikda $(0.23 \mu \mathrm{mol} / \mathrm{L})$. Whereas, seawater salinity (P.S.U.) varied with small spatial differences with an average value of 36.42 .

As far as nutrients are concerned, the reactive phosphate $\left(\mathrm{PO}_{4} 3^{-}\right)$was very low during spring and summer in all stations, whereas the maximum value was recorded at the eastern region (Algerian basin, $0.02 \mu \mathrm{mol} / \mathrm{L})$. The dissolved nitrate $\left(\mathrm{NO}_{3}{ }^{2-}\right)$ in the Algerian coast ranged between a maximum value of $0.41 \mu \mathrm{mol} / \mathrm{L}$ at Ain-Temouchent (Alboran Sea), and a minimum of $0.12 \mu \mathrm{mol} / \mathrm{L}$ in Jijel (Algerian basin). This variation is very limited for nitrite $\left(\mathrm{NO}_{2}{ }^{2-}\right)$ with a spatial mean value of $0.06 \mu \mathrm{mol} / \mathrm{L}$ at all stations of the Algerian coast. In this study, the most important values of Silicium $\left(\mathrm{SiO}_{2}\right)$ concentration were related to the stations of Alboran Sea.

The principal component analysis (PCA) and the projection of the stations and hydrological variables in the plane of the I-II axes are illustrated in figure 6 . This analysis was based on correlation matrices applied to total phytoplankton counts, phytoplankton classes, specific richness, and the physicochemical parameters. The first two axes I and II hold more than $83 \%$ of the total inertia. On this plane (I and II), some environmental variables ( $\mathrm{T}^{\circ}$ (C); S (P.S.U.), Chla; DC and $\mathrm{PO}_{4} ; \mathrm{NO}_{3}$ ) are more explanatory of the phytoplankton abundances.

Several groups of wilayas have been identified according to their distance from the coast, physicochemical characteristics and phytoplanktonic abundance (Fig. 8).

Group I corresponds to wilayas of Alboran Sea and Middle area (Tlemcen; Ain-Temouchent, Tiziouzou and Tipaza). These wilayas are associated with a dominance of diatoms and characterized by high concentration of $\mathrm{NO}_{3}{ }^{2-}$ and $\mathrm{PO}_{4}{ }^{3-}$.

Group II. Most of wilayas of the Algerian basin (Bejaia; El-Tarf; Annaba). The environmental variables are related to important phytoplankton abundances and, particularly, to those of dinoflagellates. The distance to the coast (DC) was the variable which gave a large contribution to the detachment of this 2 nd group.

Groups III and IV are associated with a single wilaya for each group (Jijel; Skikda). Group III is linked to Jijel characterized by dominance of other 


\begin{tabular}{|c|c|c|c|c|c|c|c|c|}
\hline Zone & $\mathbf{H}^{\prime}$ & $\mathbf{J}^{\prime}$ & $\mathbf{L}$ & wilaya & $\mathbf{H}^{\prime}$ & $\log S$ & $\mathbf{J}^{\prime}$ & $\mathbf{L}$ \\
\hline \multirow{3}{*}{$\begin{array}{l}\text { Alboran } \\
\text { Sea }\end{array}$} & \multirow{3}{*}{1.18} & \multirow{3}{*}{0.84} & \multirow{3}{*}{0.10} & Tlemcen & 1.22 & 1.38 & 0.88 & 0.09 \\
\hline & & & & Ain-temouchent & 1.02 & 1.11 & 0.92 & 0.11 \\
\hline & & & & Mostaganem & 1.29 & 1.80 & 0.72 & 0.10 \\
\hline \multirow{3}{*}{ Middle area } & \multirow{3}{*}{1.21} & \multirow{3}{*}{0.74} & \multirow{3}{*}{0.12} & Tipasa & 1.53 & 1.67 & 0.92 & 0.05 \\
\hline & & & & Boumerdes & 1.40 & 1.62 & 0.86 & 0.06 \\
\hline & & & & Tizi-Ouzou & 0.86 & 1.45 & 0.60 & 0.23 \\
\hline \multirow{5}{*}{$\begin{array}{l}\text { Algerian } \\
\text { basin }\end{array}$} & \multirow{5}{*}{1.29} & \multirow{5}{*}{0.75} & \multirow{5}{*}{0.13} & Bejaia & 1.05 & 1.62 & 0.65 & 0.17 \\
\hline & & & & Jijel & 0.94 & 1.30 & 0.72 & 0.18 \\
\hline & & & & Skikda & 1.85 & 2.03 & 0.92 & 0.02 \\
\hline & & & & Annaba & 1.28 & 1.61 & 0.79 & 0.08 \\
\hline & & & & El-Tarf & 1.07 & 1.87 & 0.57 & 0.25 \\
\hline
\end{tabular}

Table 3. Spatial variation of Shannon (H', H' max), Simpson (L) and Equitability “J” index per Wilaya.

phytoplanktonic taxa (Various); and group IV is linked to Skikda characterized by a high specific richness "S".

\section{CONCLUSIONS}

This study has shown remarkable phytoplankton richness with the presence of two main groups (diatoms and dinoflagellates). The qualitative study of phytoplankton based on samples collected by the CNRDPA during the period May-June 2013 by the GRINE BELKACEM vessel indicates the presence of 296 species identified in 11 stations distributed along the Algerian coast. Dinoflagellates and diatoms predominate in all stations with 103 and 180 species, respectively, along with the presence of other groups (in very low percentages) such as Coccolithophoridae and Euglenids. Our results are in line with those found in the Mediterranean by Ignatiades et al. (2009) who analyzed samples collected at nine stations (at an interval of $220 \mathrm{~km}$ minimum to a maximum of $558 \mathrm{~km}$ ), and identified 216 species including 48 diatoms (22\%), 112 dinoflagellates $(52 \%)$ and 56 coccolithophores $(25 \%)$. Besides, Moroccan Atlantic coasts presented, during the spring period 2013, a structure of the phytoplankton community composed of the same three phytoplankton groups dominated by diatoms with 47 taxa, followed by dinoflagellates with 34 taxa (Gallouli et al., 2014). The large num- ber of phytoplankton species in common with those of the different Mediterranean ecosystems shows the wide geographical distribution of this microscopic flora and its strong relationship with the circulation of water bodies in the region.

Quantitatively, we observed a highest cell density and diatoms abundance in most stations of the Alboran Sea and decreases towards the east, where diatoms are replaced by dinoflagellates. This group of phytoplankton exhibited a remarkable quantitative richness with the dominance of main genera including Prorocentrum, Gymnodinium which were already reported by Gaumer (1981) in Algerian waters. This area identified as Alboran Sea is closer to the Strait of Gibraltar and is under the influence of Modified Atlantic Water (MAW), which arrives from the Atlantic along the Spanish coast in the Alboran Sea and then joins, via the AlmeriaOran jet, the North-African coast. It runs alongside the Straits of Sicily by the Algerian current. The dominance of diatoms on the coast of the Alboran sea shows that these regions are more prone to the influence of waters coming from the Atlantic at the surface, whose physico-chemical quality is different from that found in the Algerian basin where a dominance of dinoflagellates was observed. The disappearance of diatoms and their replacement by dinoflagellates was discussed in several studies (Wasmund et al., 1998, 2013, 2016; Alheit et al., 2005). According to some authors, this decline in the Dia/Dino index indicates a worsening of the en- 
vironmental conditions. According to Lassus et al. (1982), dinoflagellates can develop with low concentrations of nutrients and salts, usually necessary for the development of phytoplankton.

The works carried out on the Algerian coasts by various authors (including Kruger, 1950; Lecal, 1952; Bernard \& Bertoldo, 1958; Bucalossi, 1960; Lalami-Taleb, 1971; Illoul, 1991) have shown that, despite the large availability of nutrient reserves, Mediterranean waters in general and Algerian waters in particular remain relatively poor in phytoplankton. The concentration of chlorophyll a is directly related to the phytoplankton biomass, which depends on the supply of nutrients and, therefore, is a parameter commonly used in many works as indicator of the trophic state of the environment (Bricker et al., 1999). Ignatiades (2005) established the trophic status of the Aegean coastal waters according to chlorophyll a concentrations. When the concentration is less than $0.5 \mathrm{mg} . \mathrm{m}-3$, the medium is oligotrophic. This allows us to consider the waters of the Algerian basin as olig- otrophic. On the other hand, temperature and salinity are factors that influence the phytoplanktonic distribution. Wasmund et al. (1998, 2013, 2016) noted that the magnitude of the diatom bloom is controlled by the minimum winter temperature. This conclusion is supported by Klais et al. (2013) who report a large proportion of dinoflagellates in the vicinity of Algiers in Mediterranean waters (Salinity $>37 \mathrm{ppm}$ ), associated with strong surface illumination and the presence of small diatoms in winter and their blossoming in early spring. Bernard \& Bertoldo (1958) in the same sector but in Atlantic-type waters, in the Alboran Sea area, reported, on the contrary, the preponderance of diatoms. Bucalossi (1960), in waters of the same type, found an influx of dinoflagellates when salinity increases.

Diversity can influence the primary production and abundance of phytoplankton; some authors have studied the relationship between productivity and biodiversity of ecosystems, but the form of the relationship is variously reported as a negative lin-

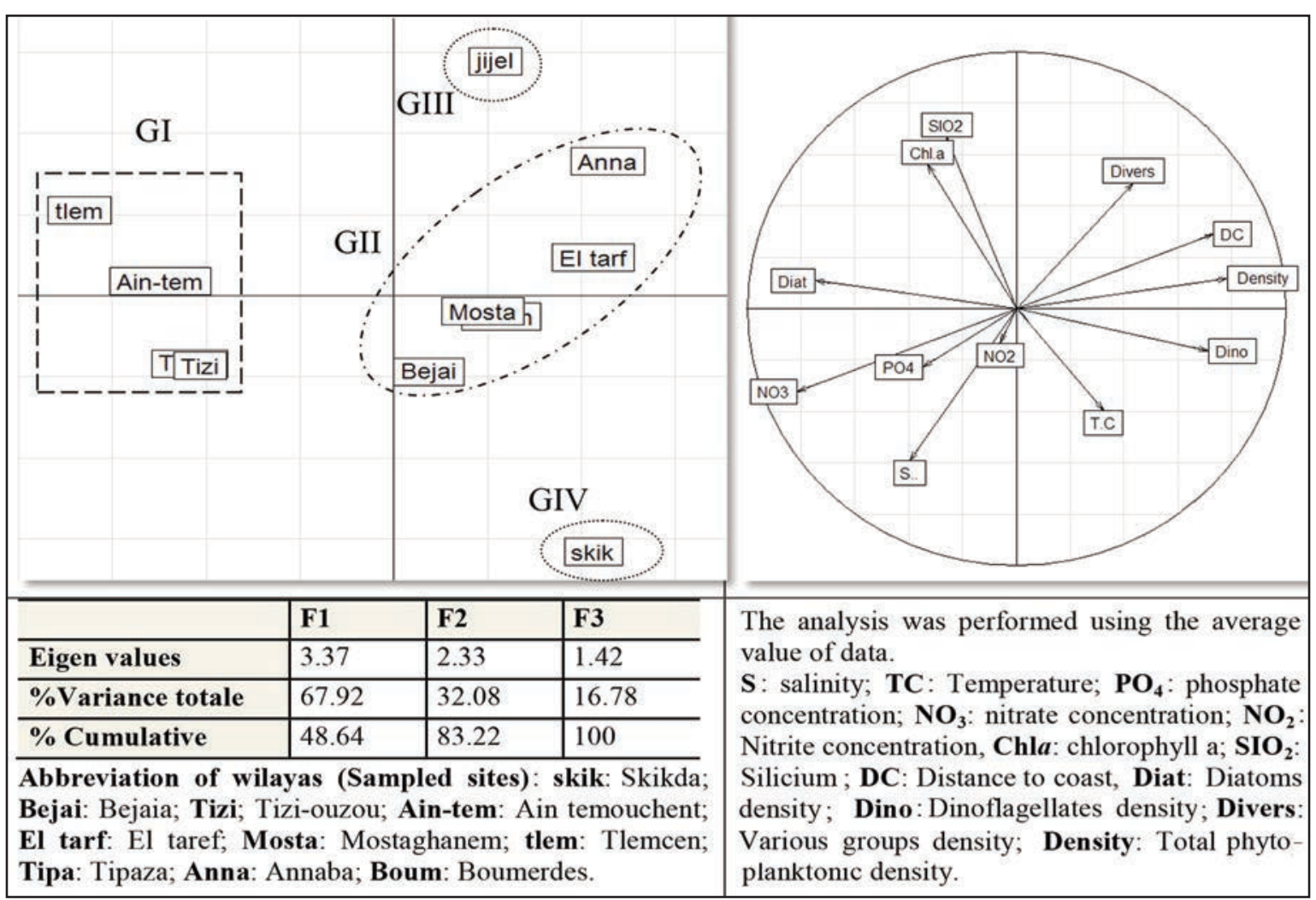

Figure 8. The principal component analysis (PCA) and the projection of the stations and hydrological variables in the plane of the I-II axes. 
ear relationship, a positive linear relationship, a unimodal relationship or, still, no relation (Chase \& Leibold, 2002; Jouenne et al., 2007; Claquin et al., 2010).

There is a negative relationship between specific richness and cell density because high production is associated with low biodiversity due to the dominance of one or a few species that exclude other taxa from the ecosystem. In the wilaya of Skikda and Tipasa a very low cell density was noted, but at the same time a good specific richness. While in Jijel, Annaba, Tizi-Ouzou and Boumerdes we have a large cell density but a low specific richness, which means that the populations in these regions are dominated by one or two species. The complexity and variability of environmental factors may explain the heterogeneity of the diversity-productivity relationship, as well as the different methodologies used to describe the degree of diversity (Napoléon et al., 2014). Alternatively, sampling strategy is another factor that may cause this fluctuation and an unbalanced distribution.

The combined action of climate change and the impact of anthropogenic activities in the Mediterranean suggest changes in the perspectives for the structure and diversity of phytoplankton populations; this study provides useful background information and a framework for future research.

Finally, this work contributes to understanding the functioning of a coastal ecosystem along with the composition of phytoplankton populations, especially according to the spatial variation. Indeed, it will be more interesting, as a prospect, to continue this study according to the different seasons thus ensuring the follow-up of phytoplankton successions throughout the year.

\section{REFERENCES}

Alheit J., Möllmann C., Dutz J., Kornilovs G., Loewe P. \& Mohrholz V., 2005. Synchronous ecological regime shifts in the central Baltic and the North Sea in the late 1980s. s.1. Journal of Marine Science, 62: 1205-1215.

Bernard F. \& Bertoldo C., 1958. Etude jour par jour de la fertilité marine élémentaire près du port d'Alger. Bulletin de l'Institut océanographique de Monaco, 1010: $1-29$.

Bricker S.B., Clement C.G., Pirhalla D.E., Orlando S.P. \& Farrow D.R.G., 1999. National Estuarine Eutroph- ication assessment. Effects of nutrients enrichment in the nation's estuaries. NOAA, National Ocean Service, Specials Projects Office and the Nation.

Bucalossi G., 1960. Etude quantitative des variations du phytoplancton dans la baie d'Alger en fonction du milieu (nov. 1959-mai 1960). Bulletin de l'Institut océanographique de Monaco, 1189: 40.

Chase L.M. \& Leibold M.A., 2002. Spatial scale dictates the productivity-biodiversity relationship. Nature, 416: 427-430.

Claquin A., Longphuit P.S., Fouillaron N., Huonnic P., Ragueneau P., Klein O. \& Leynaert C., 2010. Effects of simulated benthic fluxes on phytoplancton dynamic and photosynthetic parameters in a mesocosm experiment (Bay of Brest, France). Estuarine, Coastal and Shelf Science, 86: 93-101.

David V., Rychaert M., Karpitchev M., Bacher C., Arneaudeau V., Vidal N., Maurer D. \& Niquil N., 2012. Spatial and long-term changes of the phytoplankton diversity along the French Atlantic coast. Estuarine, Coastal and Shelf Science, 108: 37-51.

Donnelly N., Cave K., Greenway R., Hadwin J.A., Stevenson J. \& Sonuga-barke E., 2007. Visual search in children and adults: top-down and bottom-up mechanisms. Quarterly Journal of Experimental Psychology, 60: 120-136.

Gallouli E., Aziko J., Badsi H., Oulad A.H., El hafa M., Aamiri A., Regragui A. \&. Saadi A., 2014. Le peuplement phytoplanctonique de la zone maritime d'Aglou "Sud de la Baie d'Agadir, Maroc". Journal of Materials and Environmental Science, 5 (S2): 2375-2380.

Gaumer M., 1981. Evolution annuelle des communautés micro planctoniques de la baie d'Alger. Variation de la composition spécifique liée à la nature du facteur nutritionnelle limitant la biomasse algale. Thèse de doctorat 3éme cycle, P. and M. Curie University, Paris.

Helcom, 2014. Manual for Marine Monitoring in the COMBINE Programme of HELCOM.

Helcom, 2016. Outcome of the Fifth Meeting of the Working Group on the State of the Environment and Nature Conservation (State \& Conservation 5-2016). .

Ignatiades L., 2005. Scaling the trophic status of the Aegean Sea, eastern Mediterranean. Journal of Sea Research, 54: 51-57.

Ignatiades L., Gotsis-Skretas O., Pagou K. \& Krasakopoulou E., 2009. Diversification of phytoplankton community structure and related parameters along a large-scale longitudinal east-west transect of the Mediterranean Sea. Journal of Plankton Research, 31: 411-428.

Illoul H., 1991. Contribution à l'étude qualitative et quantitative et structurale des populations phytoplanctonique au large du Cap Caxine (Région Algéroise). Magister Thesis, ENSSMAL, Algeria, 214.

Jouenne F., Lefebvre S., Veron B. \& Lagadeuc Y., 2007. Phytoplankton community structure and primary 
production in small intertidal estuarine-bay ecosystem (eastern English Channel, France). Marine Biology, 151: 805-825

Klais R., Tamminen T., Kremp A., Spilling K., An B.W., Hajdu S. \& Olli K., 2013 Spring phytoplankton communities shaped by interannual weather variability and dispersal limitation: mechanisms of climate change effects on key coastal primary producers. Limnology and Oceanography, 58: 753-762. https://doi.org/10.4319/lo. 2013.58.2.0753

Lalami-Taleb R., 1971. Facteurs de répartition verticale du phytoplancton au large d'Alger. Institut océanographique d'Alger, $188 \mathrm{pp}$.

Lassus P., Paulmier G. \& Le Baut C., 1982. Rôle du phytoplancton dans les perturbations des écosystèmes côtières et estuariens. Institut scientifique et technique des pêches maritimes, $60 \mathrm{pp}$.

Lecal J., 1952. Sur une protiste pelagique rattachable aux Discoasterides. Archives de zoologie expérimentale et générale. Notes et revue, 8: 51-55.

Leterme S.C., Prime E., Mitchell J.G., Brown M.H., \& Ellis A.V., 2013. Diatom adaptability to environmental change: a case study of two Cocconeis species from high salinity areas. Diatom Research, 28: 29-35.

Meave-del Castillo, M. E. 2009. Dinoflagelados y diatomeas del Pacífico tropical mexicano. Informe final Sistema Nacional de Información sobre Biodiversidad de México-Comisión Nacional para el Conocimiento y Uso de la Biodiversidad proyecto Proyecto DJ022. México, D.F., México. http://www.conabio.gob.mx/institucion/proyectos/resultados/InfDJ022.pdf

Meave-del Castillo M.E., Zamudio-Resendiz Y.M., \& Castillo-Rivera, 2012. Riqueza fitoplanctónica de la Bahía de Acapulco y zona costera aledaña, Guerrero, México. Acta Botanica Mexicana, 100: 405-487.

Meunier A., 1915. Microplancton de la Mer Flamande. Part 2. Les Diatomacées (suite le genre Chaetoceros excepté). Mémoires du Musée Royal d'Histoire Naturelle de Belgique, 26: 8-14.

Napoléon C., Fiant L., Raimbault V., Riou P. \& Claquin P., 2014. Dynamics of phytoplankton diversity structure and primary productivity in the English Channel. Marine Ecology Progress Series, 505: 49-64.

Norme européenne NF EN 15204, 2006. Norme guide pour le dénombrement du phytoplankton par microscopie inverse (méthode Utermöhl). Comité Technique CEN/TC 230 "Analyse de l'eau”, AFNOR, 39 pp.

Plan Aquapeche 2020, 2014. Master Plan-Sectoral development of Ministry of Agriculture, Rural Development and Fisheries of Algeria, 72 pp.

Riandey V., Champalbert G., Carlotti F. \& TaupierLetage I., 2005. Zooplankton distribution related to the hydrodynamic features in the Algerian Basin (western Mediterranean Sea) in summer 1997. Deep Sea Research
Part I Oceanographic Research Papers 52: 2029-2048. https://doi.org/10.1016/j.dsr.2005.06.004

Rimet F. \& Bouchez A., 2011. Use of diatom life forms and ecological guilds to assess pesticide contamination in rivers: lotic mesocosm approaches. Ecological Indicators, 11: 489-499. https://doi.org/10.1016/j.ecolind. 2010.07.004

Schiller J., 1933-37. Dinoflagellatae (Peridineae) in monographischer Behandlung. Rabenhorst's Kryptogamenflora. Band 10, Abt. 3, Teil 1: 1-617. Akademie Verlag, Leipzig.

Somoue L., Berraho A., Ettahiri O., Elkhiati N., Ramdani M., Larissi J. \& Makaoui A., 2013. Le plancton (phytoplancton, zooplancton et ichtyoplancton) de la côte atlantique sud marocaine (Cap Boujdor-Cap Blanc). Travaux de l'Institut Scientifique, Rabat, Série Zoologie, 49: 7-18.

Taylor E.J.R., 1976. Dinoflagellates from the international Indian Ocean expedition. A report on material collected by the "Anton Bruun" 1963-64, 132, Stuttgart, 234 pp.

Utermöhl H., 1958. Zur Vervollkommnung der quantitativen. Phytoplankton-Methodik. Mitt int. Verein. theor. angew. Limnology, 9: 1-38.

Wasmund N., Nausch G. \& Matthäus W., 1998. Phytoplankton spring blooms in the southern Baltic Sea spatio-temporal development and long-term trends. Journal of Plankton Research, 20: 1099-1117. https://doi. org/10.1093/ plankt/20.6.1099

Wasmund N., Nausch G. \&. Feistel R., 2013. Silicate consumption: an indicator for long term trends in spring diatom development in the Baltic Sea. Journal of Plankton Research, 35: 393-406.

Wasmund N., Göbel J., Jaanus A., Johansen M., Jurgensone I. \&. Kownacka J., 2016 Pre-core indicator 'Diatom-Dinoflagellate index' - proposal to shift status to core indicator,". In: Document to the meeting of the HELCOM Working Group of the State of the Environment and Nature Conservation (STATE\&CONSERVATION 5-2016), 7.-11.11.2016, Tallinn. Available online at: https://portal.helcom.fi/meetings/STATE $\% 20-\% 20$ CONSERVATION\%205-2016-363/MeetingDocuments/4J-6\%20Pre-core $\% 20$ indicator $\% 20 \% \mathrm{E} 2 \% 80 \%$ 98Diatom-Dinoflagellate $\% 20$ index $\%$ E2\%80\%99\% $20 \%$ E2\%80\%93\%20proposal $\% 20$ to $\% 20$ shift $\% 20$ status $\% 20$ to $\% 20$ core $\% 20$ indicator.pdf

Wasmund N., Kownacka J., Göbel J., Jaanus A., Johansen M. \& Jurgensone I., 2017. The Diatom/Dinoflagellate Index as an Indicator of Ecosystem Changes in the Baltic Sea 1. Principle and Handling Instruction. Frontiers in Marine Sciences, 4: 22. https://doi.org/ 10.3389/fmars.2017.00022

WoRMS, 2019. World Marine Register Species, http://www.marinespecies.org/ 